\title{
Domestic sewage irrigation on dynamics of nutrients and heavy metals in soil and wheat (Triticum aestivum L.) production
}

\author{
S. R. Salakinkop • C. S. Hunshal
}

Received: 6 July 2013/ Accepted: 24 May 2014/Published online: 15 August 2014

(c) The Author(s) 2014. This article is published with open access at Springerlink.com

\begin{abstract}
Background Evaluation of urban sewage for its feasibility and potentiality as sources of irrigation water and plant nutrient is need of the hour. In this context, a field experiment was laid out in split-split plot design with three replications. Main plots constituted two types of lands (fields irrigated with sewage and bore well water since 1992). Subplots were allotted with three sources of irrigation which consisted of sewage water alone, bore well water alone (good water) and conjunction of sewage and bore well water. And sub-subplot constituted of four fertilizer levels (no fertilizer, $50 \%$ recommended rate of fertilizer (RRF), $75 \% \mathrm{RRF}$ and $100 \% \mathrm{RRF}$.

Results Crop growth in terms of photosynthesis, net assimilation rate and dry matter production significantly increased in sewage-irrigated land compared to bore wellirrigated land. Similarly, significantly higher wheat grain yield $\left(4370 \mathrm{~kg} \mathrm{ha}^{-1}\right)$, protein $(12.88 \%)$ and dry gluten $(9.22 \%)$ were obtained in field irrigated with sewage water compared to bore well-irrigated land. Sources of irrigation also differed significantly producing higher grain yield $\left(4,100 \mathrm{~kg} \mathrm{ha}^{-1}\right)$, protein $(12.81 \%)$, dry gluten $(8.97 \%)$ in sewage irrigation compared to bore well water irrigation. Enhanced activity of dehydrogenase and phosphatase enzymes and organic carbon in sewage-irrigated field contributed more to available nutrient pool of soil. Pooled results of 2 years revealed that wheat roots accumulated significantly higher amount of $\mathrm{Cr}, \mathrm{Ni}, \mathrm{Pb}$ and $\mathrm{Cd}$ in sewage-irrigated land compared to bore well-irrigated land. The same trend was noticed in stem with respect to $\mathrm{Cr}$ and
\end{abstract}

S. R. Salakinkop $(\bowtie) \cdot$ C. S. Hunshal

University of Agricultural Sciences, Dharwad,

Karnataka 580 005, India

e-mail: salakinkop@gmail.com
Ni. In general, concentration of heavy metals was higher in root followed by stem and lower in grain. The $\mathrm{Pb}$ concentration in plant parts (root, stem and grain) was not influenced by land type and sources of irrigation. None of the treatments did show accumulation of these heavy metals in wheat plant parts more than normal range found in food plants. The values of these metals were below the recommended maximum tolerable levels proposed by the Joint FAO/WHO Expert Committee on Food Additives, Summary and conclusions. In: 53rd Meeting, Rome, (1999).

Conclusion Increased wheat grain yield in sewage-irrigated land compared to bore well-irrigated land was attributed to increased soil fertility that was a result of continuous sewage irrigation. Long-term irrigation of farm lands with wastewater leads to contamination of soil and plant system with heavy metals in the study area. Wastewater-irrigated soil showed significant $(p<0.05$, $p<0.01)$ accumulation of heavy metals compared to the freshwater-irrigated soil indicating concern of their increased absorption in wheat plant. The accumulation of heavy metals in wheat plant was in the order of roots $>$ stems $>$ grains. However, all these heavy metals in plant system were lower than the recommended threshold level.

Keywords Sewage irrigation - Heavy metals accumulation · Wheat yield · Quality
Abbreviations
AAS Atomic absorption spectroscopy
DAS Days after sowing
COD Chemical oxygen demand
BOD Biochemical oxygen demand
MSL Mean sea level
RDF Recommended dose of fertilizer 


$\begin{array}{ll}\text { APHA } & \begin{array}{l}\text { American Public Health } \\ \text { Association }\end{array} \\ \text { NAR } & \text { Net assimilation rate }\end{array}$

\section{Introduction}

Environmental degradation is gaining importance of late and is confronted with both developed and developing countries. The air, water and land are vital components of environment supporting the life and polluted due to ever increasing population, unplanned urbanization and industrialization. Water pollution is a major problem in the global context. And it is the leading worldwide cause of diseases and deaths of more than 14,000 people daily (West 2006). Heavy metal toxicity can result in damaged or reduced mental and central nervous function, lower energy levels, and damage to blood composition, lungs, kidneys, liver, and other vital organs. Long-term exposure may result in slowly progressing physical, muscular, and neurological degenerative processes that mimic Alzheimer's disease, Parkinson's disease, muscular dystrophy, and multiple sclerosis. Allergies are not uncommon, and repeated long-term contact with some metals (or their compounds) may cause cancer (Hogan 2010 and AbdulWahab et al. 2011).

Integrated water resources management (IWRM) approach looks at the whole urban water cycle and across the urban-rural continuum at environmental consequences downstream, as well as socioeconomic benefits of resource recovery. This has to be combined with locally appropriate and sustainable risk reduction measures. It should also recognize that solutions require the active involvement of stakeholders from different sectors. This is a vital point in a sensitive and multi-sectoral issue like "peri-urban wastewater irrigation", which commonly concerns different ministries and municipal departments. Discharge of huge volume of wastewater originated from domestic, commercial, industrial and other public uses into natural water sources such as streams, tanks, canals, lakes and rivers makes them unfit for human usage. The concentration of toxic heavy metal in annual crops due to long-term sewage irrigation did not increase (Cambell et al. 1983; Tripathi et al. 1987; Truby and Raba 1990). In contrast, Baraman (1994) observed adverse effect of sewage irrigation on growth and yield of pulses and oil seeds. Sewage irrigation increased heavy metal accumulation in wheat plant parts (Karatas et al. 2006). The conjunctive use of sewage and good water has been recommended to improve the yield of many crops without pollution effect of toxic heavy metals (Nagaraja and Krishnamurthy (1988); Monte and Sousa (1992). Increased concentration of heavy metals like $\mathrm{Hg}$ and As has affected soil microbial activity and other heavy metals like $\mathrm{Cr}, \mathrm{Zn}$ have not affected microbial activity in soil due to sewage irrigation (Zhang et al. 2008; Oliveira and Pampulha 2006). The permissible concentration of $\mathrm{Cd}, \mathrm{Cr}, \mathrm{Cu}, \mathrm{Pb}$ and $\mathrm{Ni}$ in plant systems was $0.02,1.30,10.0,2.0$, and $10.0 \mathrm{ppm}$ respectively (World Health Organization 1996).

Global estimates of the total area under raw and diluted wastewater irrigation are still fragmentary, but might range from around 3 to 3.5 million hectares (Anonymous 2006). Every year about 300 million tonnes of organic waste is generated in India and fertilizer potential of this organic biomass has been estimated at around 15 million tonnes. In India, sewage farming alone could contribute 16,000 tonnes of nutrients per annum (Talashilkar 1989). Non-conventional water resources play great role for water augmentation to achieve food security in water-scarce countries (Qadir et al. 2007). Phytoremediation is one of the means for reducing heavy metal toxicity using microorganisms (Abdolkarim et al. (2009); Miriama (2010).Thus, irrigation with sewage provides the crop a cheap source of water, nutrients and at the same time avoids problem of its disposal. About 60 million litres of wastewater generating from HubliDharwad a twin city and second largest city in Karnataka is mainly of domestic origin and is polluting all streams coming in its way to Malaprabha river, a potable water source for Hubli-Dharwad. Utilization of this domestic sewage for crop production may reduce the amount of water pollution as well as serve as water and nutrient source for crop. Urban agriculture using wastewater provides for food, income and employment of thousands of people (Salakinkop and Hunshal 2008a). Health and environmental costs are also associated with this industry. Thus, there is a need to promote profitable yet safe practices to continue benefiting from sewage irrigation. This study therefore aimed at investigating the distribution of heavy metals within the crop plants and how it was affected by the wastewater. Study on evaluating the particular sewage on performance of crop and soil properties is need of the hour in the context of safe recycling of wastes.

\section{Materials and methods}

Description of location and experimental layout

The field experiment was conducted on farmer's field in Dharwad $\left(15^{\circ} 26^{\prime} \mathrm{N}\right.$ latitude, $75^{\circ} 07^{\prime} \mathrm{E}$ longitude, altitude of 
678 m MSL), Karnataka State, India during winter season for two consecutive years. Experimental site receives a mean annual rainfall of $762 \mathrm{~mm}$ which is fairly distributed from April to December. Both, sewage-irrigated land and bore well-irrigated lands were silt clay loam. The experiment was laid out in split-split plot design with three replications. Main plots constituted two types of lands (land irrigated with sewage and land irrigated with bore well since 1992). These two types of lands were situated in continuous, but separated by field bund. Bore well-irrigated land had never received sewage irrigation and vive-versa. Subplots allotted with sources of irrigation consisted of sewage alone, bore well water alone (best available water for irrigation) and alternate sewage and bore well water. Fertilizer levels allotted to sub-subplots consisted of control (no fertilizer, $50 \%$ recommended rate of fertilizer (RRF), $75 \%$ RRF and $100 \%$ RRF. The recommended rate/dose of chemical fertilizers to wheat crop was 100:75:50 $\mathrm{kg} \mathrm{N}, \mathrm{P}_{2} \mathrm{O}_{5}$ and $\mathrm{K}_{2} \mathrm{O}$ per hectare. The nitrogen, phosphorus and potash were applied in the form of urea, diammonium phosphate and muriate of potash, respectively, as per the treatment details. Observations on the growth and development of crop were recorded at 30, 60 days after planting (DAP) and at harvest. The crop was harvested at 105 DAP. Net assimilation rate (NAR) was worked out using total plant dry matter and leaf area recorded at 30, 60 DAP and at harvest. Grain yield and yield attributes were recorded at the time of harvesting. Treatment-wise soil samples were collected before layout of experiment and after crop harvest for analysis of NPK, micronutrients ( $\mathrm{Cu} \mathrm{Fe}, \mathrm{Mn}$ and $\mathrm{Zn}$ ) and toxic heavy metals' $(\mathrm{Cr}, \mathrm{Ni}, \mathrm{Pb}$, and $\mathrm{Cd})$ concentration. At each irrigation sewage effluent and bore well water were collected for analysis of BOD, COD and physico-chemical parameters.

\section{Planting and after care}

Bread wheat variety Triticum aestivum, DWR-162 was planted with a seed rate of $150 \mathrm{~kg} \mathrm{ha}^{-1}$ in $22.5-\mathrm{cm}$ row spacing on November 1st in both the years. Bore well water was provided immediately after planting for both the lands and thereafter the crop was irrigated (boarder strip) as per treatments based on crop critical stage approach for irrigation (crown root initiation, peak tillering production, flowering, grain formation, grain development and grain dough stage). Depth of water provided at each irrigation was $60 \mathrm{~mm}$. Crop was inter cultivated at 25 and 45 DAP. Crop was top dressed two times with $30 \mathrm{~kg}$ nitrogen in the form of urea at boot leaf stage and at anthesis. Weeds were managed with post-emergent spray of 2-4-D at the rate of 2.51 a.i. ha $^{-1}$ on 20th DAP. One hand weeding and two inter cultivations were also carried out to keep weeds under control. The major pests of the region like termites and leaf rust were not noticed on the crops in both sewage and bore well-irrigated lands.

Analysis of soil and plant samples for estimation of nutrients and heavy metals

The procedure adopted for estimation and initial soil test results are presented in Table 1 . The soil samples collected from 0 to $30 \mathrm{~cm}$ depth after harvest of crop were analysed for some of the physico-chemical properties. The total concentration of heavy metals $(\mathrm{Cu}, \mathrm{Fe}, \mathrm{Mn}, \mathrm{Zn}, \mathrm{Cr}, \mathrm{Ni}, \mathrm{Pb}$, and $\mathrm{Cd}$ ) in soil and plant samples (leaf, stem and grain) were determined by $\mathrm{HNO} 3-\mathrm{HClO} 4$ acid digestion and diluted aliquot was fed in Atomic Absorption Spectrophotometer (AAS, Shimazadu A-60 model). The available heavy metals in soil sample were extracted with AB-DTPA reagent and determined through AAS.

\section{Characterization of sewage and bore well water}

Sewage effluent samples collected during cropping season were analysed for physico-chemical properties like $\mathrm{BOD}_{5}$ (ppm), total solids $\left(\mathrm{g} \mathrm{l}^{-1}\right), \mathrm{PH}$, electric conductivity $\left(\mathrm{dS} \mathrm{m}{ }^{-1}\right)$, chlorides $\left(\mathrm{me}^{-1}\right), \mathrm{SO}_{4}\left(\mathrm{me}^{-1}\right)$, total Kjeldal $\mathrm{N}$ (ppm), total $\mathrm{P}$ (ppm), total $\mathrm{K}(\mathrm{ppm}), \mathrm{Ca}(\mathrm{ppm}), \mathrm{Mg}$ (ppm), Na (ppm), Zn (ppm), Mn (ppm), Cu (ppm), Fe (ppm) and toxic heavy metals $(\mathrm{Cr}, \mathrm{Ni}, \mathrm{Pb}$, and $\mathrm{Cd}$ ) according to Standard Methods (American Public Health Association APHA 1995). The mean data are presented in Table 1. The COD concentration was determined by the closed reflux, colorimetric method [Standard Method (SM) 5220 D]. The BOD5 was determined using the manometric method (SM 5210 D), in which the sample was digested during 5 days of incubation on a shaker base at $20 \pm 1{ }^{\circ} \mathrm{C}$. The TDS were determined using SM $2540 \mathrm{~B}$, in which the samples were centrifuged at 4,000 rpm for $20 \mathrm{~min}$ and

Table 1 Sewage effluent characters during cropping season n.10 (mean of 2 years)

\begin{tabular}{|c|c|c|c|}
\hline Character & Mean \pm SD & Character & Mean $\pm \mathrm{SD}$ \\
\hline $\mathrm{pH}$ & $7.54 \pm 0.36$ & $\mathrm{Mg}(\mathrm{ppm})$ & $6.38 \pm 0.19$ \\
\hline $\mathrm{EC}\left(\mathrm{dS} \mathrm{m} \mathrm{m}^{-1}\right)$ & $0.79 \pm 0.09$ & $\mathrm{Na}(\mathrm{ppm})$ & $47.6 \pm 1.62$ \\
\hline Total solids $\left(\mathrm{g}^{-1}\right)$ & $708.5 \pm 17.1$ & $\mathrm{Zn}(\mathrm{ppm})$ & $0.31 \pm 0.02$ \\
\hline $\mathrm{BOD}_{5}(\mathrm{ppm})$ & $141.4 \pm 10.5$ & $\mathrm{Cu}(\mathrm{ppm})$ & $0.16 \pm 0.01$ \\
\hline Chlorides(me $1^{-1}$ ) & $8.40 \pm 0.62$ & $\mathrm{Fe}(\mathrm{ppm})$ & $1.24 \pm 0.08$ \\
\hline $\mathrm{SO}_{4}\left(\mathrm{me}^{-1}\right)$ & $7.75 \pm 0.47$ & $\mathrm{Mn}(\mathrm{ppm})$ & $0.15 \pm 0.01$ \\
\hline Kjeldal N (ppm) & $29.2 \pm 1.22$ & $\mathrm{Cd}(\mathrm{ppm})$ & BDL \\
\hline Total P (ppm) & $13.1 \pm 0.63$ & $\mathrm{Ni}(\mathrm{ppm})$ & BDL \\
\hline Total K (ppm) & $54.7 \pm 1.35$ & $\mathrm{Cr}(\mathrm{ppm})$ & $0.004 \pm 0.00$ \\
\hline $\mathrm{Ca}(\mathrm{ppm})$ & $10.85 \pm 0.13$ & $\mathrm{~Pb}(\mathrm{ppm})$ & $0.029 \pm 0.00$ \\
\hline$E \operatorname{coli}\left(10^{-3}\right)$ & 1.20 & & \\
\hline
\end{tabular}


Table 2 Methods employed to estimate physico-chemical properties of experimental soils and initial results of soil test

\begin{tabular}{|c|c|c|c|}
\hline Properties & Sewage land & Borewell-irrigated land & Method \\
\hline \multicolumn{4}{|l|}{ Physical properties } \\
\hline \multicolumn{4}{|l|}{ Particle size analysis } \\
\hline Coarse sand $(\%)$ & 6.1 & 6.5 & International pipette method (piper, 1966) \\
\hline Fine sand $(\%)$ & 16.5 & 15.7 & \\
\hline Silt $(\%)$ & 18.5 & 18.1 & \\
\hline Clay $(\%)$ & 58.5 & 59.3 & \\
\hline Bulk density $\left(\mathrm{Mg} \mathrm{m}^{-3}\right)$ & 1.23 & 1.32 & Core sampler method (Black 1965) \\
\hline \multicolumn{4}{|l|}{ Chemical properties } \\
\hline Electrical conductivity $\left(\mathrm{dS} \mathrm{m}^{-1}\right)$ & 0.42 & 0.31 & EC bridge (Jackson 1967) \\
\hline $\mathrm{pH}$ & 7.30 & 7.95 & 1:2.5 soil:water suspension (Jackson 1967) \\
\hline Organic carbon $(\%)$ & 0.86 & 0.43 & Walkley and Black's wet oxidation method (Jackson 1967) \\
\hline Available $\mathrm{N}\left(\mathrm{kg} \mathrm{ha}^{-1}\right)$ & 235.8 & 141.50 & Alkaline permanganate method (Subbiah and Asija 1956) \\
\hline Available $\mathrm{P}_{2} \mathrm{O}_{5}\left(\mathrm{~kg} \mathrm{ha}^{-1}\right)$ & 29.5 & 17.90 & Olsen's method \\
\hline Available $\mathrm{K}_{2} \mathrm{O}\left(\mathrm{kg} \mathrm{ha}^{-1}\right)$ & 458.6 & 387.50 & Extraction with NH40AC (Black 1965) \\
\hline \multicolumn{4}{|l|}{ Micronutrients (ppm) } \\
\hline $\mathrm{Cu}$ & 1.61 & 1.18 & Extraction with DTP A reagent (Lindeasy and Narwell 1978) \\
\hline $\mathrm{Fe}$ & 6.50 & 4.06 & \\
\hline $\mathrm{Mn}$ & 18.50 & 12.20 & \\
\hline $\mathrm{Zn}$ & 0.42 & 0.23 & \\
\hline
\end{tabular}

dried to a constant weight at $105^{\circ} \mathrm{C}$. The samples were filtered within $12 \mathrm{~h}$ of collection, and the filter was frozen prior to extraction. Total coliform and E. coli analyses were performed using a chromogenic medium. The samples were analysed using the Quanti-Tray ${ }^{\circledR} / 2000$ Inc. method and were incubated at $37{ }^{\circ} \mathrm{C}$ for $24 \mathrm{~h}$. Yellow wells indicated total coliforms, and yellow/fluorescent wells indicated the presence of E. coli.

\section{Determination of biophysical parameters of plant growth}

Chlorophyll, transpiration and photosynthesis rate of crop were measured on fully expanded six leaves at anthesis using $\mathrm{CO}_{2}$ gas analyser (CID model CI-301) during sunny day at 12.30 PM. Chlorophyll, transpiration and photosynthesis rate were expressed as $\mathrm{mg} \mathrm{g}^{-1}, \mu \mathrm{g} \mathrm{H}_{2} \mathrm{O} \mathrm{cm}^{2} \mathrm{~s}^{-1}$ and $\mathrm{CO}_{2} \mathrm{dm}^{2} \mathrm{~h}^{-1}$, respectively.

Estimation of soil enzymes activity

Dehydrogenase enzyme activity in soil samples was determined by following the procedures as described by Casida et al. (1964). The values were expressed as mg TPF $\mathrm{g}^{-1}$ day $^{-1}$. Similarly alkaline phosphatase enzyme activity of soil samples was determined by procedure of Evazi and Tabutavbai (1979) and estimations were expressed as mg P-nitrophenol $\mathrm{g}^{-1} \mathrm{~h}^{-1}$.
Statistical analysis

The data of various parameters on soil and plant growth, biochemical, biophysical and yield attributes recorded for 2 years were analysed in triplicates and subjected to ANOVA (analysis of variance) in accordance to field design (split-split plot) using M-Stat package to quantify and evaluate the sources of variation. All the pooled data collected from split plot design analysis were subjected to Duncan's multiple range test (DMRT). The treatment means were compared at a significant level of 0.05 and ranking of treatments denoted by alphabets. The treatments denoted by different letters in the each column of tables and figures represent significantly different among the treatments.

\section{Results and discussions}

Result of initial soil analysis showed that soil EC $\left(\mathrm{dS} \mathrm{m}^{-1}\right)$, $\mathrm{pH}$, organic carbon (\%), available $\mathrm{N}\left(\mathrm{kg} \mathrm{ha}^{-1}\right), \mathrm{P}_{2} \mathrm{O}_{5}$ $\left(\mathrm{kg} \mathrm{ha}^{-1}\right), \mathrm{K}_{2} \mathrm{O}\left(\mathrm{kg} \mathrm{ha}^{-1}\right)$, DTPA extractable $\mathrm{Cu}$ (ppm), Fe (ppm), Mn (ppm), and $\mathrm{Zn}$ (ppm) in sewage-irrigated land were $0.42,7.3,0.86,235.8,29.5,458.6,1.61,6.50,18.50$ and 0.42 ; whereas for bore well-irrigated land these values were $0.31,7.95,0.43,141.5,17.90,387.5,1.18,4.06,12.20$ and 0.23 , respectively (Table 2 ). 
Table 3 Grain yield, Protein, gluten, and ash per cent in wheat grains as influenced by lands, sources of irrigation and fertilizer levels (mean of 2 years)

\begin{tabular}{|c|c|c|c|c|c|c|c|c|}
\hline Treatment & $\begin{array}{l}\text { Grain yield } \\
\left(\mathrm{Mg} \mathrm{ha}^{-1}\right)\end{array}$ & $\begin{array}{l}\text { Ears/ } \\
\text { sq m }\end{array}$ & $\begin{array}{l}1,000 \text { grain } \\
\text { weight }(\mathrm{g})\end{array}$ & $\begin{array}{l}\text { Ear length } \\
(\mathrm{cm})\end{array}$ & $\begin{array}{l}\text { Protein } \\
(\%)\end{array}$ & $\begin{array}{l}\text { Wet gluten } \\
(\%)\end{array}$ & $\begin{array}{l}\text { Dry gluten } \\
(\%)\end{array}$ & $\begin{array}{l}\text { Ash } \\
(\%)\end{array}$ \\
\hline \multicolumn{9}{|l|}{ Land } \\
\hline Sewage irrigated & $4.368 \mathrm{a}$ & $417.80 \mathrm{a}$ & $37.47 \mathrm{a}$ & $8.15 \mathrm{a}$ & $12.88 \mathrm{a}$ & $28.83 a$ & $9.22 \mathrm{a}$ & $1.52 \mathrm{a}$ \\
\hline Borewell irrigated & $3.365 b$ & $388.18 b$ & $32.99 \mathrm{~b}$ & $7.04 \mathrm{~b}$ & $12.22 \mathrm{~b}$ & $27.17 \mathrm{~b}$ & $7.95 b$ & $1.51 \mathrm{~b}$ \\
\hline $\mathrm{CD}(5 \%)$ & 0.3250 & 7.939 & 1.847 & 0.752 & 0.259 & 2.162 & 0.530 & 0.009 \\
\hline \multicolumn{9}{|l|}{ Source of irrigation } \\
\hline Sewage & $4.100 \mathrm{a}$ & $422.70 \mathrm{a}$ & $36.64 a$ & $7.92 \mathrm{a}$ & $12.81 \mathrm{a}$ & $28.41 \mathrm{a}$ & $8.97 \mathrm{a}$ & $1.51 \mathrm{a}$ \\
\hline Borewell & $3.557 \mathrm{c}$ & $380.40 \mathrm{c}$ & $33.20 \mathrm{~b}$ & $6.94 b$ & $12.21 \mathrm{~b}$ & $27.14 \mathrm{a}$ & $8.07 \mathrm{~b}$ & $1.51 \mathrm{a}$ \\
\hline Alternate & $3.943 \mathrm{a}$ & $405.90 \mathrm{~b}$ & $35.87 \mathrm{a}$ & $7.94 \mathrm{a}$ & $12.64 \mathrm{a}$ & $28.46 a$ & $8.71 \mathrm{a}$ & $1.51 \mathrm{a}$ \\
\hline $\mathrm{CD}(5 \%)$ & 0.2266 & 6.274 & 1.440 & 0.381 & 0.025 & 1.709 & 0.418 & 0.007 \\
\hline \multicolumn{9}{|l|}{ Fertility level } \\
\hline No fertilizer & $2.979 \mathrm{a}$ & $357.20 \mathrm{c}$ & $29.32 \mathrm{c}$ & $6.13 c$ & $11.78 \mathrm{c}$ & $25.94 \mathrm{c}$ & $7.93 d$ & $1.50 \mathrm{~b}$ \\
\hline $50 \% \mathrm{RDF}$ & $3.664 \mathrm{~b}$ & $401.30 \mathrm{~b}$ & $35.35 b$ & $7.77 \mathrm{~b}$ & $12.33 \mathrm{~b}$ & $27.70 \mathrm{~b}$ & $8.43 \mathrm{c}$ & $1.51 \mathrm{a}$ \\
\hline $75 \% \mathrm{RDF}$ & $4.304 \mathrm{a}$ & $425.20 \mathrm{a}$ & $37.96 \mathrm{a}$ & $8.20 \mathrm{a}$ & $12.90 \mathrm{a}$ & $28.85 a$ & $8.81 \mathrm{~b}$ & $1.51 \mathrm{a}$ \\
\hline $100 \% \mathrm{RDF}$ & $4.518 \mathrm{a}$ & $428.30 \mathrm{a}$ & $38.32 \mathrm{a}$ & $8.29 \mathrm{a}$ & $13.21 \mathrm{a}$ & $29.52 \mathrm{a}$ & $9.17 \mathrm{a}$ & $1.51 \mathrm{a}$ \\
\hline $\mathrm{CD}(5 \%)$ & 0.2433 & 7.864 & 0.723 & 0.210 & 0.349 & 0.807 & 0.208 & 0.005 \\
\hline
\end{tabular}

Data with same letter do not differ statistically

Influence of land types on crop growth, yield and grain quality

Crop raised in sewage-irrigated land showed better growth and photosynthesis due to more chlorophyll content. Enhanced growth and net assimilation in sewage-irrigated land resulted in significantly higher grain yield $\left(4,368 \mathrm{~kg} \mathrm{ha}^{-1}\right)$ compared to bore well-irrigated land which produced $3,365 \mathrm{~kg} \mathrm{ha}^{-1}$ grains (Table 3). The principle factors involved in better growth and yield could be increased soil fertility as evidenced by higher available plant nutrients like nitrogen, phosphorus, potassium, sulphur, copper, iron, manganese and zinc in sewage-irrigated land (Fig. 1). Grain quality was assessed to determine protein, ash and gluten content and their possible contamination by microbes and heavy metals. Quality of wheat depends on complex number of factors relating to how it is grown, milled and adapts to an end use in different kinds of products. Sewage-irrigated land produced grains with higher protein (12.8\%) compared to grains obtained from bore well-irrigated land $(12.2 \%)$ which could be due to high availability of nutrients especially nitrogen in soil $\left(240 \mathrm{~kg} \mathrm{ha}^{-1}\right)$ and further nitrogen content in grain $(2.05 \%)$. Nitrogen is a major component of amino acids. The concentration of nitrogen in both soil and plant was significantly higher in sewage-irrigated land (Salakinkop and Hunshal 2008b).

Influence of sources of irrigation on crop growth, yield and grain quality

Sources of irrigation also differed significantly having higher chlorophyll, photosynthesis, dry matter production
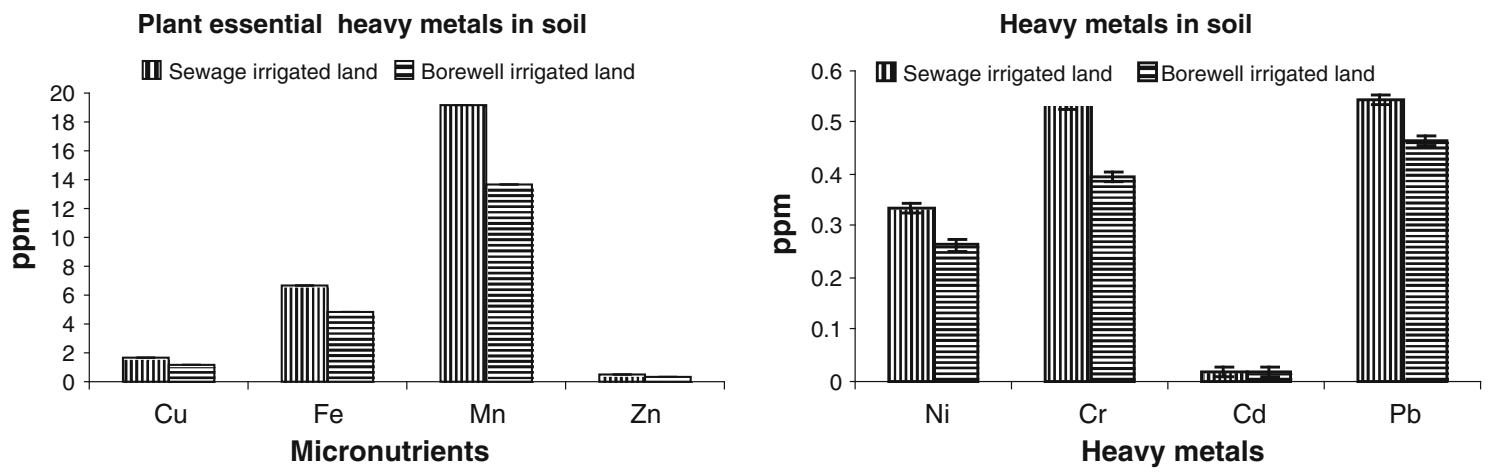

Fig. 1 AB-DTPA extractable micronutrients and heavy metal accumulation in sewage- and bore well-irrigated lands since 1992 
and grain yield $\left(4,100 \mathrm{~kg} \mathrm{ha}^{-1}\right)$ in sewage irrigation and alternate irrigation $\left(3,904 \mathrm{~kg} \mathrm{ha}^{-1}\right)$ compared to bore well water irrigation $\left(3,555 \mathrm{~kg} \mathrm{ha}^{-1}\right)$ (Table 3$)$. The conjunctive use of sewage and good water was also recommended to improve the yield of many crops without pollution effect (Nagaraja and Krishnamurhy 1988; Monte and Sousa 1992). Number of ears $\mathrm{m}^{-2}$, 1,000 grain weight, ear length and spikelets ear ${ }^{-1}$ produced in crop irrigated with sewage water were significantly higher than in bore well-irrigated crop. Improved yield of rice was noticed with use of urban water and compost (Yoganand and Reddy 2004). Improved performance of crop (yield and yield attributes) in sewageirrigated fields was due to increased chlorophyll content and photosynthesis rate compared to bore well-irrigated crop (Table 4). De Carvalho et al. (2012) also recorded improved legume performance with sewage irrigation. Among the sources of irrigation, sewage irrigation and alternate irrigation have added to nitrogen contribution and thus increased the $\mathrm{N}$ content and thus increasing protein and grain yield. About $75 \%$ nitrogen present in sewage is utilized by plants (Skulte 1956).

Influence of land types on dynamics of heavy metals in soil and plant system

Sewage-irrigated land recorded significantly higher concentration of heavy metals $(\mathrm{Cu}, \mathrm{Fe}, \mathrm{Mn}, \mathrm{Zn}, \mathrm{Cr}, \mathrm{Ni}, \mathrm{Pb}$, and $\mathrm{Cd}$ ) compared to bore well water-irrigated land due to gradual accumulation of heavy metals in sewage-irrigated soil (Liu et al. 2005; Afshin et al. 2008). Roots of wheat accumulated significantly higher amount of $\mathrm{Cr}, \mathrm{Ni}, \mathrm{Pb}$ and
$\mathrm{Cd}$ in sewage land than in bore well-irrigated land. The same trend was noticed in stem with respect to $\mathrm{Cr}$ and $\mathrm{Ni}$. The contribution of heavy metals from sewage water since the start of irrigation had increased their accumulation in sewage-irrigated land (Table 5; Figs. 1,2) and further their uptake by roots. Grains did not contain $\mathrm{Pb}$ in both the lands in detectable level. On the contrary, vegetables accumulated significant amount of Cd and Ni (Afshin et al. 2008). There was no significant difference between lands with respect to $\mathrm{Cd}$ and $\mathrm{Cr}$ content in wheat grain (Tables 5 and 6; Figs. 3, 4, 5). Accumulation of heavy metals in plant was in the order of roots $>$ stems $>$ grains. Soumya Niyogi et al. (1997) also recorded higher accumulation of heavy metals in roots of mangrove plant (Sonneratia apetala) followed by stem and leaf. As these heavy metals are immobile in plant more so with $\mathrm{Pb}$, they have not been translocated to stem and then into grains through xylem stream at the rate of their absorption. Root crops exclude these metals from edible roots. Thus, accumulation of heavy metals need not be a food chain hazard where normal domestic effluents are applied to land.

Influence of sources of irrigation and fertilizer levels on dynamics of heavy metals in soil and plant system

Among the sources of irrigation, in sewage irrigation treatments there was improvement in soil heavy metal content like $\mathrm{Cu}, \mathrm{Fe}$ and $\mathrm{Mn}$ which are known as essential plant growth micronutrients (Fig. 2). Legume crop irrigated with sewage water absorbed significantly higher amount of essential micronutrients (De Carvalho et al.

Table 4 Total chlorophyll, transpiration, photosynthesis and net assimilation rate (NAR) at flowering as influenced by lands, sources of irrigation and fertilizer levels (mean of 2 years)

\begin{tabular}{|c|c|c|c|c|c|}
\hline Treatment & $\begin{array}{l}\text { Plant height } \\
(\mathrm{cm})\end{array}$ & $\begin{array}{l}\text { Total dry matter } \\
\left(\mathrm{g} \text { plant }^{-1}\right)\end{array}$ & $\begin{array}{l}\text { Chlorophyll } \\
\left(\mathrm{mg} \mathrm{g}^{-1}\right)\end{array}$ & $\begin{array}{l}\text { Transpiration } \\
\left(\mu \mathrm{g} \mathrm{H} 20 \mathrm{~cm}^{2} \mathrm{~s}^{-1}\right)\end{array}$ & $\begin{array}{l}\text { Photosynthesis } \\
\left(\mathrm{mg} \mathrm{CO} \mathrm{dm}^{2} \mathrm{~h}^{-1}\right)\end{array}$ \\
\hline \multicolumn{6}{|l|}{ Land } \\
\hline Sewage irrigated & $84.13 \mathrm{a}$ & $136.93 \mathrm{a}$ & $2.66 a$ & $14.24 \mathrm{a}$ & $44.89 \mathrm{a}$ \\
\hline Borewell irrigated & $79.19 b$ & $114.07 \mathrm{~b}$ & $2.20 \mathrm{~b}$ & $14.04 \mathrm{~b}$ & $37.65 b$ \\
\hline $\mathrm{CD}(5 \%)$ & 4.352 & 5.346 & 0.118 & 0.744 & 1.523 \\
\hline \multicolumn{6}{|l|}{ Source of irrigation } \\
\hline Sewage & $82.64 a$ & $134.40 \mathrm{a}$ & $2.54 \mathrm{a}$ & $14.22 \mathrm{a}$ & $42.71 \mathrm{a}$ \\
\hline Borewell & $78.27 \mathrm{~b}$ & $115.80 \mathrm{c}$ & $2.29 b$ & $14.00 \mathrm{a}$ & $39.80 \mathrm{c}$ \\
\hline Alternate & $81.08 \mathrm{ab}$ & $126.30 \mathrm{~b}$ & $2.45 \mathrm{a}$ & $14.21 \mathrm{a}$ & $41.31 \mathrm{~b}$ \\
\hline $\mathrm{CD}(5 \%)$ & 4.140 & 4.225 & 0.093 & 0.602 & 0.773 \\
\hline \multicolumn{6}{|l|}{ Fertility level } \\
\hline No fertilizer & $76.86 \mathrm{~b}$ & $86.30 \mathrm{~d}$ & $2.25 \mathrm{c}$ & $13.95 \mathrm{a}$ & $38.26 \mathrm{~d}$ \\
\hline $50 \% \mathrm{RDF}$ & $79.49 b$ & $128.40 \mathrm{c}$ & $2.36 \mathrm{~b}$ & $14.28 \mathrm{a}$ & $40.58 \mathrm{c}$ \\
\hline $75 \% \mathrm{RDF}$ & $82.71 \mathrm{a}$ & $140.30 \mathrm{~b}$ & $2.52 \mathrm{a}$ & $14.22 \mathrm{a}$ & $42.42 \mathrm{~b}$ \\
\hline $100 \% \mathrm{RDF}$ & $83.61 \mathrm{a}$ & $147.00 \mathrm{a}$ & $2.59 \mathrm{a}$ & $14.13 \mathrm{a}$ & $43.84 \mathrm{a}$ \\
\hline $\mathrm{CD}(5 \%)$ & 2.655 & 3.06 & 0.086 & 0.486 & 0.8930 \\
\hline
\end{tabular}

Data with same letter do not differ statistically 
Table 5 Nickel and chromium concentration in wheat root, stem and grain before harvest as influenced by lands, sources of irrigation and fertilizer levels (mean of 2 years)

\begin{tabular}{|c|c|c|c|c|c|c|}
\hline \multirow[t]{2}{*}{ Treatment } & \multicolumn{3}{|c|}{ Nickel (ppm) } & \multicolumn{3}{|c|}{ Chromium (ppm) } \\
\hline & Root & Stem & Grain & Root & Stem & Grain \\
\hline \multicolumn{7}{|l|}{ Land } \\
\hline Sewage irrigated & $2.330 \mathrm{a}$ & $1.480 \mathrm{a}$ & $0.540 \mathrm{a}$ & $2.106 \mathrm{a}$ & $1.414 \mathrm{a}$ & $0.473 \mathrm{a}$ \\
\hline Borewell irrigated & $1.740 \mathrm{~b}$ & $1.140 \mathrm{~b}$ & $0.354 b$ & $1.655 \mathrm{~b}$ & $1.203 \mathrm{~b}$ & $0.353 \mathrm{a}$ \\
\hline $\mathrm{CD}(5 \%)$ & 0.125 & 0.1022 & 0.084 & 0.194 & 0.048 & 0.135 \\
\hline \multicolumn{7}{|l|}{ Source of irrigation } \\
\hline Sewage & $2.259 \mathrm{a}$ & $1.372 \mathrm{a}$ & $0.470 \mathrm{a}$ & $1.991 \mathrm{a}$ & $1.331 \mathrm{a}$ & $0.425 \mathrm{a}$ \\
\hline Borewell & $1.875 \mathrm{c}$ & $1.237 \mathrm{~b}$ & $0.415 \mathrm{a}$ & $1.822 \mathrm{~b}$ & $1.257 \mathrm{a}$ & $0.378 \mathrm{a}$ \\
\hline Alternate & $1.985 \mathrm{~b}$ & $1.335 \mathrm{a}$ & $0.445 \mathrm{a}$ & $1.868 \mathrm{ab}$ & $1.336 \mathrm{a}$ & $0.438 \mathrm{a}$ \\
\hline $\mathrm{CD}(5 \%)$ & 0.098 & 0.0801 & 0.068 & 0.118 & 0.0388 & 0.125 \\
\hline \multicolumn{7}{|l|}{ Fertility level } \\
\hline No fertilizer & $2.064 \mathrm{a}$ & $1.249 \mathrm{~b}$ & $0.440 \mathrm{~b}$ & $1.991 \mathrm{a}$ & $1.322 \mathrm{~b}$ & $0.422 \mathrm{ab}$ \\
\hline $50 \% \mathrm{RDF}$ & $1.996 \mathrm{~b}$ & $1.257 \mathrm{~b}$ & $0.430 \mathrm{~b}$ & $1.873 \mathrm{c}$ & $1.298 \mathrm{~b}$ & $0.406 \mathrm{bc}$ \\
\hline $75 \% \mathrm{RDF}$ & $2.006 \mathrm{~b}$ & $1.357 \mathrm{a}$ & $0.430 \mathrm{~b}$ & $1.823 \mathrm{~d}$ & $1.260 \mathrm{c}$ & $0.392 \mathrm{c}$ \\
\hline $100 \% \mathrm{RDF}$ & $2.092 \mathrm{a}$ & $1.395 \mathrm{a}$ & $0.480 \mathrm{a}$ & $1.888 \mathrm{~b}$ & $1.353 \mathrm{a}$ & $0.435 \mathrm{a}$ \\
\hline $\mathrm{CD}(5 \%)$ & 0.051 & 0.0534 & 0.024 & 0.0148 & 0.029 & 0.021 \\
\hline
\end{tabular}

Data with same letter do not differ statistically

2012). But other toxic heavy metals like $\mathrm{Cr}, \mathrm{Ni}, \mathrm{Pb}$, and $\mathrm{Cd}$ did not accumulate in soil significantly under sewage irrigation. Heavy metals' accumulation was known to increase in plants due to sewage irrigation but extent of accumulation varies among varieties and crops depending on concentration of heavy metals in effluent and frequency of application. Rice crop irrigated with sewage water had 1.4to 2.0-fold higher $\mathrm{Pb}$ content than that irrigated with natural water (Ji and Juile 1994).

Sewage water irrigation did not increase the heavy metals in grains over other sources of irrigation but had increased the $\mathrm{Cr}$ and $\mathrm{Ni}$ in roots (Table 6, Fig. 4). The $\mathrm{Pb}$
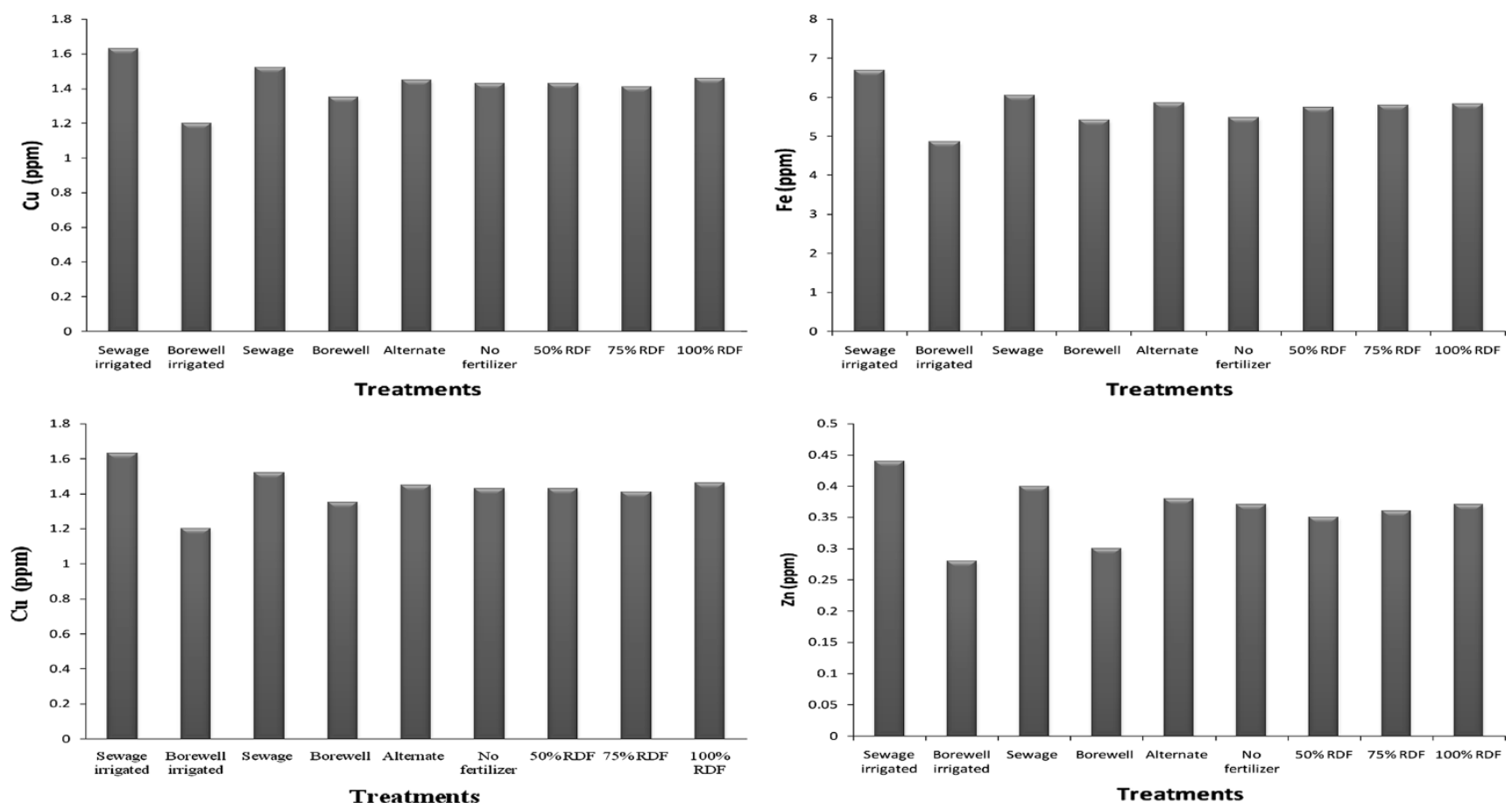

Fig. 2 AB-DTPA extractable micronutrient accumulation in soil as influenced by sources of irrigation and fertilizer levels 
Table 6 Cadmium and lead concentration in wheat root, stem and grain before harvest as influenced by lands, sources of irrigation and fertilizer levels (mean of 2 years)

\begin{tabular}{|c|c|c|c|c|c|c|}
\hline \multirow[t]{2}{*}{ Treatment } & \multicolumn{3}{|c|}{ Cadmium (ppm) } & \multicolumn{3}{|c|}{ Lead (ppm) } \\
\hline & root & stem & grain & root & stem & grain \\
\hline \multicolumn{7}{|l|}{ Land } \\
\hline $\begin{array}{l}\text { Sewage } \\
\text { irrigated }\end{array}$ & $0.280 \mathrm{a}$ & $0.134 \mathrm{a}$ & $0.094 a$ & $0.150 \mathrm{a}$ & $1.029 \mathrm{a}$ & - \\
\hline $\begin{array}{l}\text { Borewell } \\
\text { irrigated }\end{array}$ & $0.194 b$ & $0.116 \mathrm{a}$ & $0.067 \mathrm{a}$ & $0.052 b$ & $1.004 \mathrm{a}$ & - \\
\hline $\mathrm{CD}(5 \%)$ & 0.0261 & 0.0192 & 0.049 & 0.0290 & 0.012 & \\
\hline \multicolumn{7}{|c|}{ Source of irrigation } \\
\hline Sewage & $0.245 \mathrm{a}$ & $0.129 a$ & $0.870 \mathrm{a}$ & $0.130 \mathrm{a}$ & $1.016 \mathrm{a}$ & - \\
\hline Borewell & $0.230 \mathrm{a}$ & $0.120 \mathrm{a}$ & $0.074 a$ & $0.087 \mathrm{~b}$ & $1.010 \mathrm{a}$ & - \\
\hline Alternate & $0.235 \mathrm{a}$ & $0.125 \mathrm{a}$ & $0.081 \mathrm{a}$ & $0.097 \mathrm{~b}$ & $1.014 \mathrm{a}$ & - \\
\hline $\mathrm{CD}(5 \%)$ & 0.0179 & 0.0167 & 0.016 & 0.0179 & 0.0066 & \\
\hline \multicolumn{7}{|l|}{ Fertility level } \\
\hline No fertilizer & $0.232 \mathrm{~b}$ & $0.119 \mathrm{c}$ & $0.073 \mathrm{c}$ & $0.109 \mathrm{a}$ & $1.014 \mathrm{a}$ & - \\
\hline $50 \% \mathrm{RDF}$ & $0.228 b$ & $0.124 b$ & $0.079 b$ & $0.105 b$ & $1.012 \mathrm{a}$ & - \\
\hline $75 \% \mathrm{RDF}$ & $0.237 \mathrm{ab}$ & $0.124 b$ & $0.081 b$ & $0.098 \mathrm{a}$ & $1.013 \mathrm{a}$ & - \\
\hline $100 \% \mathrm{RDF}$ & $0.249 \mathrm{a}$ & $0.132 \mathrm{a}$ & $0.088 \mathrm{a}$ & $0.108 \mathrm{a}$ & $1.015 \mathrm{a}$ & - \\
\hline $\mathrm{CD}(5 \%)$ & 0.0148 & 0.0047 & 0.005 & 0.0148 & 0.0047 & \\
\hline
\end{tabular}

Data with same letter do not differ statistically

concentration in plant (roots, stem and grains) was not influenced by sources of irrigation, lands and fertilizer levels and also their interactions being immobile at any concentration in soil. Sewage water also did not increase the $\mathrm{Cd}$ accumulation in plant. Inorganic fertilizers contain significantly higher amount of available form of heavy metals which also has been evident by higher amount of extractability of available heavy metals $(\mathrm{Cr}, \mathrm{Cd}$ and $\mathrm{Pb})$ (Fig. 3). However, there is need to estimate dietary daily intake of other metals (DIM) which are essential to human beings taking into account all the food and vegetable consumption in the context of intake limits of $\mathrm{Cu}, \mathrm{Fe}, \mathrm{Zn}$, and $\mathrm{Mn}$ in adults that range from 1.2 to $3.0 \mathrm{mg}, 10.0$ to $50.0 \mathrm{mg}, 5.0$ to $22.0 \mathrm{mg}$ and 2.0 to $20.0 \mathrm{mg}$, respectively (World Health Organization 1996).

Influence of land types and sources of irrigation on some soil properties

Dehydrogenase enzyme in soil is responsible for decomposition of organic matter. The higher organic carbon content in sewage-irrigated land $(0.89 \%)$ increased the activity of dehydrogenase enzyme which is reported as soil ecotoxilogial testing parameter and thereby improved available nutrient status especially nitrogen in sewageirrigated land (Tables 7, 8). Higher activity of dehydrogenase enzyme and microbes in sewage-amended soil than in unamended soil was reported by many researchers (Shrikanthimathi 1990; Zhang et al. 2008). Microbial population, cellulase activity and dehydrogenase activity had no persistent correlation with soil heavy metals and at the same time they have positive correlation with soil nutrients status (Yan Zhang et al. 2008).

Sewage irrigation supported the population of N-fixers and fungi involved in organic matter decomposition

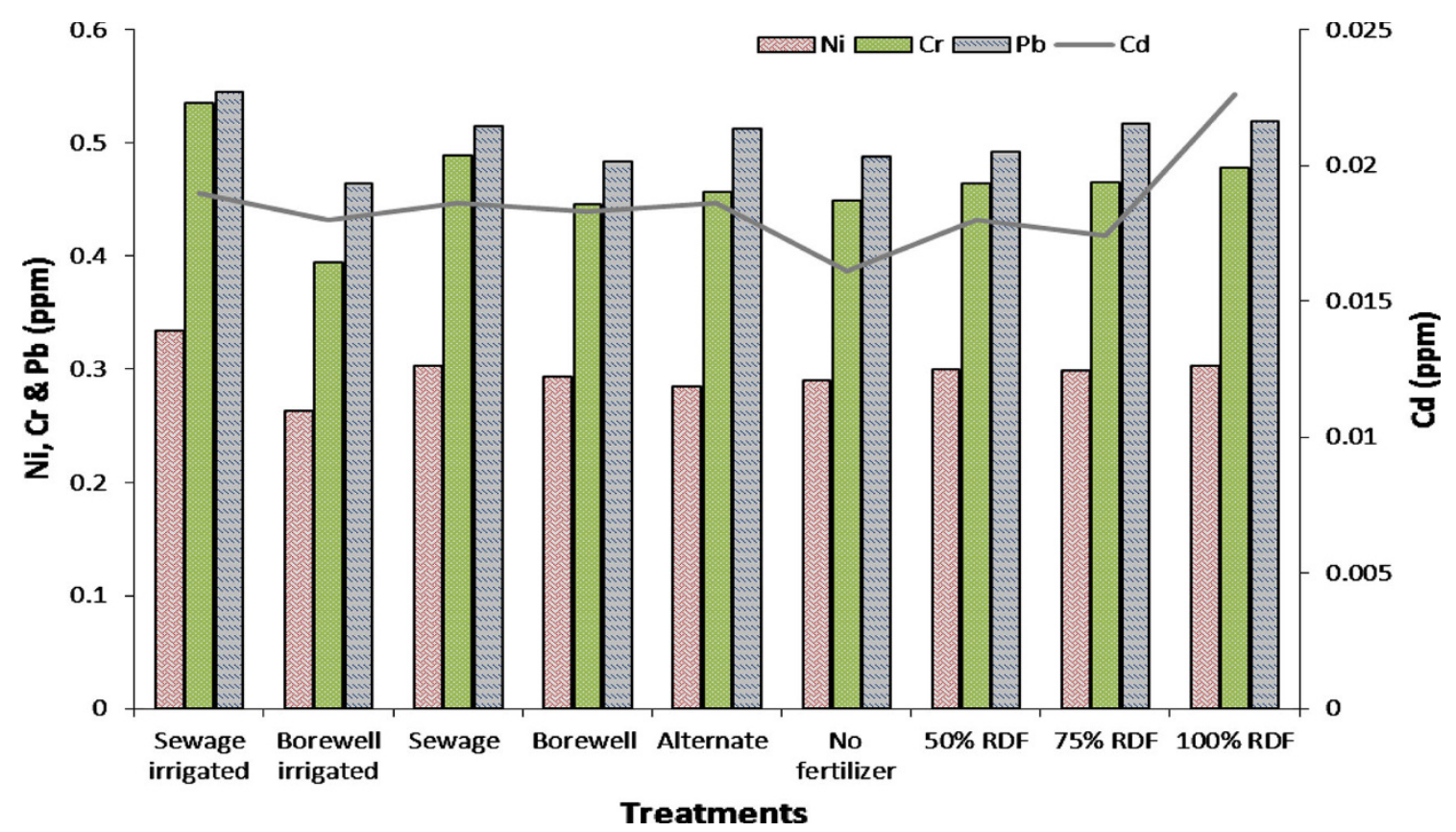

Fig. 3 AB-DTPA extractable heavy metal accumulation in soil as influenced by lands, sources of irrigation and fertilizer levels 
Nickel content in differnt parts of wheat crop

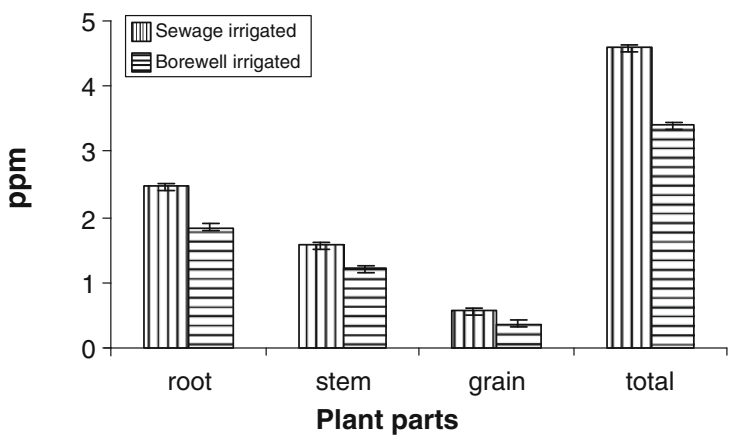

Cadmium content in differnt parts of wheat crop

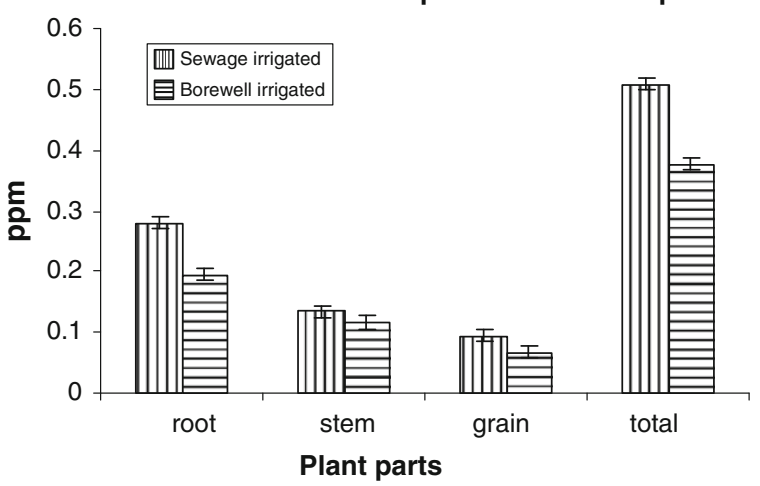

Chromium content in differnt parts of wheat crop

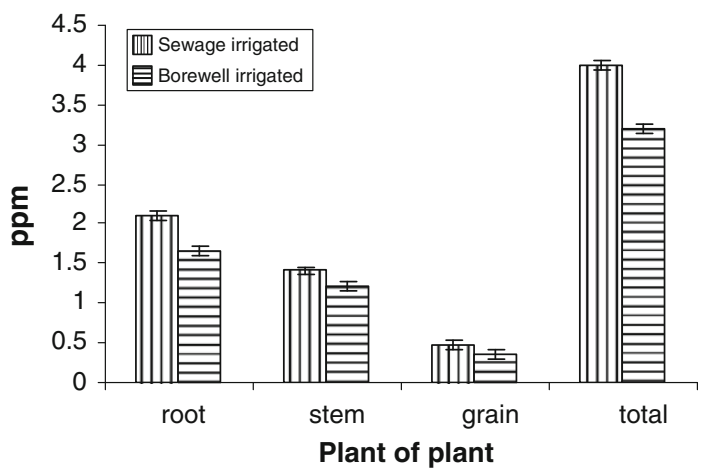

Lead content in differnt parts of wheat crop

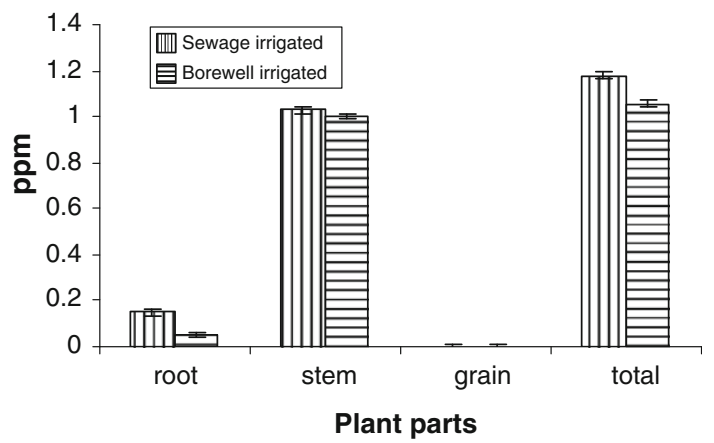

Fig. 4 Heavy metal accumulation in different parts of wheat crops at the time of harvest

(Kulkarni Leela 1981). Deficiency of micronutrients especially $\mathrm{Zn}, \mathrm{Fe}, \mathrm{Cu}$ and $\mathrm{Mn}$ is common in black cotton soil due to intensive cultivation of HYV, hybrids, monocropping and non-availability of sufficient organic sources of nutrient to correct the deficiency. Sewage effluent in present study corrected these deficiencies and also supplemented the part of the major plant nutrients as effluent water contained considerably good amount of total $\mathrm{N}(29.2 \mathrm{ppm})$, total $\mathrm{P}$ (13.1 ppm), total $\mathrm{K}(54.7 \mathrm{ppm}), \mathrm{Zn}(0.31 \mathrm{ppm}), \mathrm{Cu}$ $(0.16 \mathrm{ppm}), \mathrm{Fe}(1.24 \mathrm{ppm})$ and $\mathrm{Mn}(0.15 \mathrm{ppm})$. The nutrient content of the effluent used for irrigating wheat crop is presented in Table 1. Observed BOD levels proved that domestic-originated sewage of present study was weak (less oxygen demand) and fit for irrigation. Sewage effluent having BOD within 100-150 ppm was preferred for irrigation (Juwarkar 1992) and for wheat crop, it could be $260 \mathrm{ppm}$. Organic matter and nutrients present in sewage water acted as source of carbon and energy for microbes. Further, increased beneficial microbes must have also contributed to available nutrient pool as they decompose the organic matter added through sewage. The maximum decomposition of organic matter could be evidenced by significantly the higher dehydrogenase activity in sewage water irrigation (35.3 $\mathrm{mg} \mathrm{TPF}^{-1} \mathrm{day}^{-1}$ ) followed by alternate irrigation (33.6 mg TPF g ${ }^{-1}$ day $^{-1}$ ).

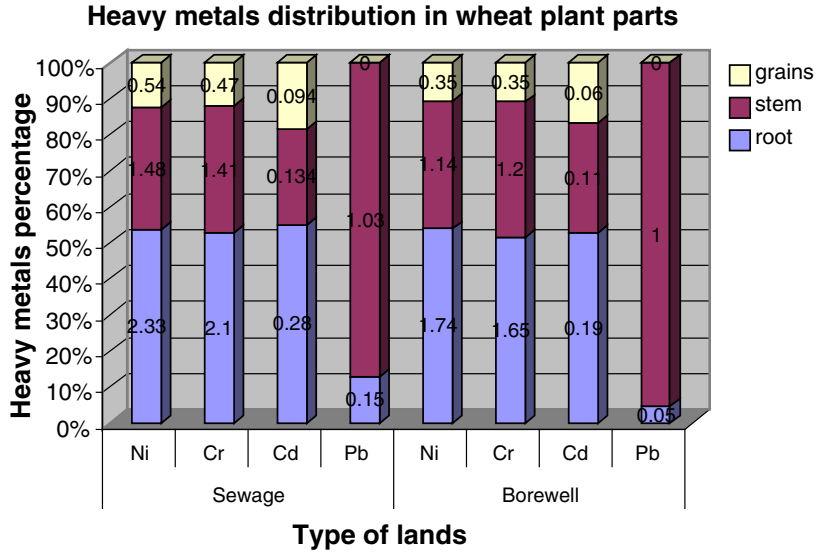

Fig. 5 Proportion of heavy metal distribution in wheat plant parts

\section{Conclusions}

Pooled data showed increased wheat grain yield by $30 \%$ in sewage-irrigated land compared to bore well-irrigated land due to increased soil fertility as a result of continuous sewage irrigation. Among the fertilizer levels, $100 \% \mathrm{RRF}$ and $75 \%$ RRF were on par with each other with respect to wheat grain yield. This emphasized the importance of sewage irrigation in saving $25 \%$ cost on fertilizer. Heavy 
Table 7 Dehydrogenase activity (mg TPF $\mathrm{g}^{-1} \mathrm{day}^{-1}$ ) in soil and soil properties as influenced by lands and sources of irrigation

\begin{tabular}{|c|c|c|c|c|c|c|c|c|c|}
\hline \multirow[t]{2}{*}{ Treatment } & \multicolumn{3}{|c|}{ Dehydrogenase (mg TPF g ${ }^{-1}$ day $^{-1}$ ) } & \multicolumn{3}{|c|}{ Soil properties } & \multicolumn{3}{|c|}{ Major nutrient status $\left(\mathrm{kg} \mathrm{ha}^{-1}\right)$} \\
\hline & First year & Second year & Pooled & $\mathrm{OC}(\%)$ & $\mathrm{pH}$ & $\mathrm{BD}\left(\mathrm{Mg} / \mathrm{m}^{3}\right)$ & Avail. N & Avail. P2O5 & Avail. $\mathrm{K} 2 \mathrm{O}$ \\
\hline \multicolumn{10}{|l|}{ Land } \\
\hline Sewage irrigated & $34.83 a$ & $42.38 \mathrm{a}$ & $38.61 \mathrm{a}$ & $0.89 a$ & $7.24 \mathrm{a}$ & $1.23 \mathrm{a}$ & $238.0 \mathrm{a}$ & $30.9 a$ & $461.6 \mathrm{a}$ \\
\hline Borewell irrigated & $27.17 \mathrm{~b}$ & $28.30 \mathrm{~b}$ & $27.74 b$ & $0.435 b$ & $7.65 b$ & $1.31 \mathrm{~b}$ & $175.2 b$ & $24.5 b$ & $392.8 b$ \\
\hline $\mathrm{CD}(5 \%)$ & 2.15 & 4.28 & 2.11 & 0.024 & 0.093 & 0.023 & 6.90 & 1.87 & 16.20 \\
\hline \multicolumn{10}{|l|}{ Source of irrigation } \\
\hline Sewage & $32.50 \mathrm{a}$ & $38.15 \mathrm{a}$ & $35.33 \mathrm{a}$ & $0.70 \mathrm{a}$ & $7.35 \mathrm{c}$ & $1.25 \mathrm{a}$ & $219.7 \mathrm{a}$ & $29.52 \mathrm{a}$ & $434.6 \mathrm{a}$ \\
\hline Borewell & $28.63 b$ & $32.50 \mathrm{~b}$ & $30.56 \mathrm{c}$ & $0.60 \mathrm{c}$ & $7.56 \mathrm{a}$ & $1.31 \mathrm{a}$ & $189.9 \mathrm{c}$ & $25.48 b$ & $414.5 b$ \\
\hline Alternate & $31.88 \mathrm{a}$ & $35.39 \mathrm{ab}$ & $33.63 b$ & $0.67 \mathrm{~b}$ & $7.44 b$ & $1.27 \mathrm{a}$ & $210.5 b$ & $28.23 \mathrm{a}$ & $432.6 \mathrm{a}$ \\
\hline $\mathrm{CD}(5 \%)$ & 2.64 & 4.44 & 1.66 & 0.018 & 0.051 & 0.139 & 5.45 & 1.47 & 12.60 \\
\hline
\end{tabular}

Means followed by same letter do not differ significantly at 5 percent level of significance

Table 8 Alkaline phosphatase and acid phophatase activity (mg P-nitrophenol $\mathrm{g}^{-1} \mathrm{~h}^{-1}$ ) in soil as influenced by lands and sources of irrigation

\begin{tabular}{|c|c|c|c|c|c|c|}
\hline \multirow[t]{2}{*}{ Treatment } & \multicolumn{3}{|c|}{ Alkaline phosphatase (mg P-nitrophenol $\mathrm{g}^{-1} \mathrm{~h}^{-1}$ ) } & \multicolumn{3}{|c|}{ Acid phophatase mg P-nitrophenol $\mathrm{g}^{-1} \mathrm{~h}^{-1}$} \\
\hline & First year & Second year & Pooled & First year & Second year & Pooled \\
\hline \multicolumn{7}{|l|}{ Land } \\
\hline Sewage irrigated & $99.77 \mathrm{a}$ & $107.41 \mathrm{a}$ & $103.59 \mathrm{a}$ & $39.98 \mathrm{a}$ & $45.18 \mathrm{a}$ & $42.58 \mathrm{a}$ \\
\hline Borewell irrigated & $88.45 \mathrm{~b}$ & $88.92 b$ & $88.19 \mathrm{~b}$ & $35.16 \mathrm{~b}$ & $34.21 \mathrm{~b}$ & $34.69 b$ \\
\hline $\mathrm{CD}(5 \%)$ & 3.80 & 5.42 & 2.79 & 1.35 & 4.43 & 1.80 \\
\hline \multicolumn{7}{|l|}{ Source of irrigation } \\
\hline Sewage & $96.92 b$ & $101.00 \mathrm{a}$ & $98.94 b$ & $41.00 \mathrm{a}$ & $42.33 \mathrm{a}$ & $41.66 \mathrm{a}$ \\
\hline Borewell & $83.74 \mathrm{c}$ & $86.66 b$ & $85.20 \mathrm{c}$ & $35.10 \mathrm{~b}$ & $37.15 b$ & $36.12 \mathrm{c}$ \\
\hline Alternate & $101.70 \mathrm{a}$ & $105.40 \mathrm{a}$ & $103.50 \mathrm{a}$ & $36.63 b$ & $39.63 b$ & $38.13 b$ \\
\hline $\mathrm{CD}(5 \%)$ & 4.65 & 4.99 & 2.20 & 1.66 & 3.98 & 1.42 \\
\hline
\end{tabular}

Means followed by same letter do not differ significantly at 5 percent level of significance

metal dynamics revealed a build-up in soil with continuous sewage water irrigation. However, long-term irrigation of farm lands with sewage wastewater leads to contamination of wheat grains with heavy metals in this study area. Wastewater-irrigated soil showed significant $(p<0.05$, $p<0.01$ ) accumulation of heavy metals compared to the freshwater-irrigated soil indicating concern of their increased absorption in wheat plant system. However, all the heavy metals in plant system were lower than the recommended tolerable levels proposed by Joint FAO/ WHO Expert Committee on Food Additives. The study confirms that domestic sewage after its characterization and confirmation for its feasibility could be utilized as source of irrigation and nutrients. The accumulation of heavy metals in wheat plant was in the order of roots $>$ stems $>$ grains. However, grains did not contain $\mathrm{Pb}$ and $\mathrm{Cd}$ in detectable level. And there is need for continuous monitoring of potential toxic heavy metals in sewage-soilplant continuum and in food chain.

Conflict of interest We authors declare that they we have no competing interests
Open Access This article is distributed under the terms of the Creative Commons Attribution License which permits any use, distribution, and reproduction in any medium, provided the original author(s) and the source are credited.

\section{References}

Abdolkarim C (2009) Phytoremediation of heavy-metal-polluted soils: screening for new accumulator plants in Angouran mine (Iran) and evaluation of removal ability. Ecotoxicol Environ Saf 72(5):1349-1353

Abdul-Wahab SA, Marikar FA (2011) The environmental impact of gold mines: pollution by heavy metals. Cent Eur J Eng 2(2):304-313

American Public Health Association APHA (1995) Standard methods for the examination of water and wastewater.19th (ed.) APHA. Washington, DC

Anonymous (2006) Recycling realities: managing health risks to make wastewater an asset International water management institute P.O. Box 2075, Colombo, Sri Lanka, p 1-6. Web site: www.iwmi.cgiar. org/waterpolicybriefing/index.asp. Accessed 23 July 2014

Barman SC (1994) A comparative study of mature plants grown in polluted and unpolluted soil using different pulses and oil seeds. In: symposium on Environmental Pollution, impact of technology on Quality of life, Shantineketan, India, p 21-23 
Black CA (1965) Methods of soils analysis Part II, Chemical and microbial properties.American Society of Agronomy Inc., Madison

Cambell WF, Miller RW, Reynolds JH, Schreeg TM (1983) Alfalfa, sweet corn and wheat responses to long-term application of municipal waste water to crop land. J Environ Qual 12:243-249

De Carvalho FG, da Silva AJN, Melo HN de S, Melo JLde S (2012) Effect of irrigation with sewage effluent and rhizobia inoculation on growth of tropical tree legumes in northeast Brazil. Int $\mathbf{J}$ Agric For 2(1): 72-78

Hogan M (2010) Heavy metal. Encyclopedia of Earth. National Council for Science and the Environment. In: Monosson E. and Cleveland C. (eds.) Washington, D.C

Jackson ML (1967) Soil chemical analysis. Prentice Hall of India Pvt. Ltd, New Delhi

Ji X, Juile R (1994) Determination of trace lead in rice of sewage irrigation by graphite furnace atomic- absorption spectrometry. Chin Rice Res News Lett 2:5-6

Joint FAO/WHO Expert Committee on Food Additives (1999) Summary and conclusions. In: 53rd Meeting, Rome, June 1-10

Juwarkar AS (1992) Biological and industrial wastes as source of plant nutrients. In: HLS Tandon (ed) Fertilizer, organic manure, recyclable wastes and biofertilizers. Fertiliser Development and Consultation Organisation, New Delhi, p 79-90

Karatas M, Dursun S, Argun EGE (2006) Heavy metal accumulation in wheat plants irrigated by waste water. Cell Chem Technol 40(7):575-579

Kulkarni Leela S (1981) Studies on micro-organisms associated with sewage-irrigated soils and crop plants.Ph.D thesis marathawada University Aurangabad. Kuster E and William S T 1964 Selection of media for isolation of streptomycetes. Nature 202:926-929

Lindeasy WL, Narwell WA (1978) Development of DTPA Soil test for $\mathrm{Zn}, \mathrm{Fe}, \mathrm{Mn}$ and $\mathrm{Cu}$. J Am Soc Soil Sci 42:421-428

Liu W-H, Zhao J-Z, Ouyang Z-V, Soderlund L, Liu G-H (2005) Impact of sewage irrigation on heavy metal distribution and contamination in Beijing, China. Environ Int 31(6):805-812

Monte HM, Sousa (1992) Effect on crops of irrigation with facultative pond effluent. Water Sci Technol 26:1603-1613

Nagaraja DN, Krishnamurthy K (1988) Rice varieties for sewage effluent and without fertilizers. Mysore J Agric Sci 22:433-435

Niyogi S, Basu S, Mitra A, Choudhary A (1997) Trace metal concentration in vegetative parts of Sonneratia apetala. Indian J Environ Health 39(1):69-72
Oliveira A, Pampulha ME (2006) Effect of long term heavy metal contamination on soil microbial characteristics. J Biosci Bio Eng 102(3):157-161

Qadir M, Sharma BR, Bruggeman A, Choukr-Allah R, Karajeh F (2007) Non-conventional water resources and opportunities for water augmentation to achieve food security in water scarce countries. Agric Water Manag 87:2-22

Qishlaqi A, Moore F, Forghhani G (2008) Impact of untreated waste water on soil and crop in Shiraz suburban area, SW Iran. Environ Monit Assess 141:257-273

Salakinkop SR, Hunshal CS (2008a) Influence of long term utilization of domestic sewage on performance of wheat and health of farmers. J Ecobiol 22(1):45-51

Salakinkop SR, Hunshal CS (2008b) Studies on production and characterization of enriched Urban waste composts and their influence on crops productivity. J Environ Sci Eng 50(1):83-88

Skulte BF (1956) Irrigation with sewage effluent. Sew Ind Waste 28(1):36-46

Subbiah BV, Asija GL (1956) A rapid procedure for the estimation of available nitrogen in soils. Curr Sci 25:259-260

Talashilkar C (1989) Recycling of urban wastes in agriculture. In: Mishra PC (ed) Soil pollution and microrganisms. Ashis publishing house, New Delhi, pp 177-207

Tripathi BD, Kumari D, Dwivedi RL (1987) Effect of sewage irrigation on soil properties and yield of potato. Geol Ecol Tropics 12:133-141

Truby P, Raba A (1990) Heavy metal accumulation by garden plants from sewage farm waste water. Agribiol Res 43(139): 146

West L (2006) World Water Day, A Billion People Worldwide lack Safe Drinking Water pp. 31-41

World Health Organization (1996) Health criteria other supporting information. In Guidelines for Drinking water Quality, vol. 2, 2nd edn. Geneva, pp 31-388

Yoganand SB, Reddy VC (2004) Growth and sustainability of rice varieties as influenced by urban compost and inorganic fertilizers. J. Ecobiol 16(4):279-285

Zhang Y, Zhang H-W, Su Z-C, Zhang C-G (2008a) Soil microbial characteristics under long-term heavy metal stress: a case study in Zhangshi wastewater irrigation area, Shenyong. Pedophere 18(1):1-10

Zhang YL, Wang DRQ, Zhang J (2008b) Effect of long term sewage irrigation on agricultural soil in Shandong. Eur $\mathrm{J}$ soil Biol 44(1):84-91 